\title{
Biosorption of Heavy Metals from Synthetic Wastewater by Using Macro Algae Collected from Iraqi Marshlands
}

\author{
Shaymaa Bahaa', Israa Abdulwahab Al-Baldawi', Safaa Rasheed Yaseen', \\ Siti Rozaimah Sheikh Abdullah²
}

1 Department of Biochemical Engineering, Al-Khwarizmi College of Engineering, University of Baghdad, Baghdad, Iraq

2 Department of Chemical and Process Engineering, Faculty of Engineering and Built Environment, Universiti Kebangsaan Malaysia, 43600 UKM Bangi, Selangor, Malaysia

* Corresponding author's e-mail: israa@kecbu.uobaghdad.edu.iq or israaukm@gmail.com

\begin{abstract}
Biosorption is fast, effective and low cost process. It takes place in a wide range of temperature and it can be used for almost all types of heavy metals. The aim of this study was to investigate the ability of locally collected green macro algae to remove copper, chromium and cadmium from synthetic wastewater. The fresh algae were converted into dry powder as biosorbent. In the investigations, $1 \mathrm{~g}$ of macro algae powder was exposed to synthetic waste water contaminated with $10 \mathrm{mg} / \mathrm{L}$ concentration of copper, chromium and cadmium in separate exposure for 2 hours. The best removal efficiency for copper, chromium and cadmium were $70 \%, 80 \%$ and $85 \%$, respectively, from the initial concentration of $10 \mathrm{mg} / \mathrm{L}$. While macro algae are abundantly available in marshlands of south Iraq, it can be preferably utilized as biosorbent to remove heavy metals from the industrial wastewater.
\end{abstract}

Keywords: adsorption, Cladophora, copper, cadmium, chromium, aqueous solutions.

\section{INTRODUCTION}

With the development of industries and technologies, huge amounts of toxic wastes, organic materials, metalloids and heavy metals are released to our environment (Ayangbenro and $\mathrm{Ba}-$ balola, 2017). The metals with high density, comparing with water, are well-known as heavy metals (Gupta and Diwan, 2016). The heavy metal pollution has been recognized as a serious problem because these metals are non-biodegradable elements and they have a great danger to human, animals and plants (He and Chen, 2014; Huang et al., 2016; Gong et al., 2019). Biosorption could be defined as the ability of biological materials such as bacteria (Titah et al., 2019, Titah et al., 2018; Purwanti et al., 2019), plants (Ismail et al. 2019; Kamaruzzaman et al. 2019) and algae (Deng et al., 2007) to adsorb heavy metal ions from aqueous solutions by the physico-chemical pathways of uptake. The conventional treatments used for metals removal, such as chemical precipitation, membrane separation, evaporation, electro winning or resin ionic exchange, could be very expensive, and sometimes not effective enough (Aydın and Bulut, 2008). The biological treatments, based on living or non-living microorganisms and plants, provide the reduction of toxic metals in a cost-effective and ecofriendly ways (Kadukova and Virc, 2005; Sedlakova-Kadukova et al., 2019). In this study, the locally collected green algae were tested as a biosorbent for the removal of copper, chromium and cadmium from synthetic wastewater by means of biosorption. The biosorption process involved converting the green algae into dry powder and using it in the experiments. Heavy metals pose serious danger to the human health, for example, cadmium can cause various diseases such as pneumonitis, pulmonary oedema and even death (Pyrzyńska and Pietrowski, 2019). In turn, trivalent chromium, which can be converted to the more toxic hexavalent chromium in the presence of oxidants, consequently causes different diseases and issues ( $\mathrm{Li}$, Zeng and 
Fan, 2009; Gong et al., 2019). On the other hand, traces of copper are necessary for the development of enzyme synthesis, tissues and bones (Tunali et al., 2009), but the excessive $\mathrm{Cu}$ (II) may damage for eye and liver and the imbalance in cellular processes causing the Wilson, Menkes, Alzheimer's and Parkinson's diseases (Ofomaja, 2010; Awual et al., 2016; Hu et al., 2017). Unlike most Iraqi researchers, who used imported algae in their experiments, all the experiments in this study were carried out by means of the locally collected algae to minimize the cost and to pay attention to tons of algae that remain unused.

\section{MATERIALS AND METHODS}

\section{Biosorbent preparation}

The green algae were harvested from Um Alnia'aj marshland, Maysan province in south of Iraq. After harvesting, the macro algae were cleaned from any residuals and washed with distilled water several times. Then, they were dried using oven $\left(250^{\circ} \mathrm{C}\right.$ max, Gemmy, Taiwan) at $70^{\circ} \mathrm{C}$ for $24 \mathrm{~h}$ (Lee and Chang, 2011). After drying, the biomass was ground with a blender and finally sieved with standard sieve to obtain $0.18-0.25 \mathrm{~mm}$ biosorbent particle size.

\section{Simulated wastewater preparation}

In order to prepare $10 \mathrm{ppm}$ of simulated wastewater, a specific amount of copper chloride was weighed and dissolved in $1000 \mathrm{ml}$ distilled water. The same procedure was repeated for the preparation of cadmium sulfate and chromium nitrate. Then, the standard solutions were kept in tightly closed bottles and used in the experiments.

\section{Instruments}

The produced samples of macro algae biosorbent were dried in an electrical oven $\left(250^{\circ} \mathrm{C}\right.$ max, Gemmy, Taiwan). The $\mathrm{pH}$ measurements of solutions were carried out with a $\mathrm{pH}$ meter (WTW, Germany). In order to determine the concentrations of $\mathrm{Cu}, \mathrm{Cd}$ and $\mathrm{Cr}$ before and after the adsorption test, the atomic absorption spectrometer with a hollow cathode lamp (AA 680 model made by SHIMADZU, Japan) was used. The functional groups present on macro algae were analyzed by using FT-IR spectroscopy (SHIMADZU, Japan) in the range of $400-4000 \mathrm{~cm}^{-1}$.

\section{Batch biosorption experiments}

The factors of $\mathrm{pH}$, mixing speed and contact time influencing the biosorption efficiency of cladophora macro algae were investigated. The batch experiments were performed under different ranges of the factors, $\mathrm{pH}(2-9)$, mixing speed (50-150) and contact time (5-240 $\mathrm{min})$ to evaluate the optimum conditions for the heavy metals removal. The experiments were performed in $100 \mathrm{~mL}$ baker containing $25 \mathrm{~mL}$ solution with $10 \mathrm{ppm}$ concentration of copper, cadmium and chromium separately and $1 \mathrm{~g} / \mathrm{L}$ of biosorbent at room temperature $\left(20^{\circ} \mathrm{C}\right)$. After ending contact time, suspension was separated by filter paper, and then the remaining concentration of the metal ions was determined by atomic absorption spectrometer. The removal percentage of the ions was calculated by means of the following equation:

$$
\% \text { Re moval }=\left(\frac{\mathrm{C}_{0}-\mathrm{C}_{\mathrm{e}}}{\mathrm{C}_{0}}\right) \times 100
$$

where: $C_{0}$ and $C_{e}(\mathrm{mg} / \mathrm{L})$ are the liquid phase concentrations of the ions initially and at equilibrium, respectively.

The effect of $\mathrm{pH}$, mixing speed and contact time metals ions adsorption: The initial $\mathrm{pH}$ of solutions was adjusted by $0.1 \mathrm{M} \mathrm{HCl}$. It was also investigated in the alkaline range and adjusted by $0.1 \mathrm{M} \mathrm{NaOH}$. The experiments were conducted at mixing speed between a range of (50-150) rpm. In order to estimate the best experiment time, range of (5-240) minutes was taken.

\section{RESULTS AND DISCUSSION}

\section{Effect of initial pH}

Many adsorption studies showed the important effect of $\mathrm{pH}$ on biosorption of heavy metals (Ballester et al., 1999; Deng et al., 2007). The main effect of $\mathrm{pH}$ is the protonation and deprotonation of the functional groups on the biomass (Bilal, Rasheed and Eduardo, 2018). The effect of $\mathrm{pH}$ on $\mathrm{Cu}$ (II) adsorption was investigated and the results were shown in (Fig.1). At $\mathrm{pH}$ 2, the removal percentage was $29 \%$ and $59 \%$ at $\mathrm{pH} 4$, while it was $70 \%$ at $\mathrm{pH}$ of 5.4. There was a clear competition for sorption sites between $\mathrm{Cu}$ (II) and $\mathrm{H}^{+}$protons at low $\mathrm{pH}$; thus, the removal efficiency of biosorbent decreased along with $\mathrm{pH}$ decreased. On the other hand, when $\mathrm{pH}$ was modified higher than 
the normal $\mathrm{pH}$ of the solution (which was 5.4), the copper ions was removed by depositing by forming $\mathrm{Cu}(\mathrm{OH})_{2}$ as a deposit (Aydin and Bulut, 2008; Labidi et al., 2016). The same like in the case of copper, the cadmium removal efficiency decreased at $\mathrm{pH}<3$ while the precipitation of cadmium ions occurred at the $\mathrm{pH}$ value higher than 7 (Fig. 1). The best removal efficiency of cadmium was near the neutralized pH value (Huang et al., 2016). Unlike copper and cadmium, the chromium removal efficiency did not affect by the decreased $\mathrm{pH}$ (Fig. 1) but when $\mathrm{pH}$ went to alkaline, the chromium ions started to precipitate (Li, Zeng and Fan, 2009).

\section{Effect of mixing speed}

The mixing speed effect was investigated at $0,50,70,100$ and $150 \mathrm{rpm}$. As known in the transport phenomena, mixing is usually used to reduce the resistance of boundary layer and could increase the removal efficiency, but in some cases the sorption efficiency decreased with the increasing in mixing speed. The removal efficiency without mixing for $\mathrm{Cu}$ (II), $\mathrm{Cr}$ (III) and $\mathrm{Cd}$ (II) was $70 \%, 80 \%$ and $85 \%$ respectively. In $\mathrm{Cu}$ (II) and Cd (II) adsorption experiments, the removal efficiency decreased when the mixing speed increased as shown in Figure 2. This might have happened because of the weak binding that occurred between metal ions and the functional groups on the adsorbent surface. On the other hand, the Cr (III) removal efficiency was not affected by changing mixing speed and stayed at $80 \%$. The difference between the $\mathrm{Cu}$ (II) and $\mathrm{Cd}$ (II) behavior and $\mathrm{Cr}$ (III) behavior may be due to the difference in oxidation number of the ions, which give high attraction or adhesion ability on the sorbent surface for high oxidation state ions.

\section{Effect of contact time}

Figure $3 a, b$ and $3 c$ shows the effect of contact time on the removal of $\mathrm{Cu}$ (II), $\mathrm{Cd}$ (II) and $\mathrm{Cr}$ (III), respectively, from a solution of $10 \mathrm{~g} / \mathrm{L}$ metal

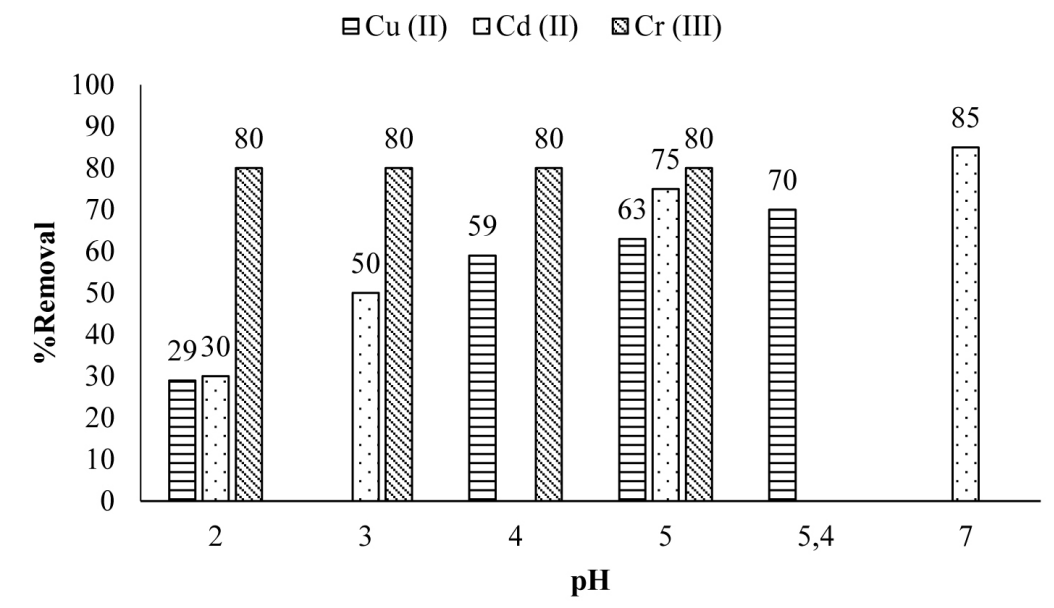

Fig. 1. pH effect on $\mathrm{Cu}$ (II), $\mathrm{Cd}$ (II) and $\mathrm{Cr}$ (III) removal

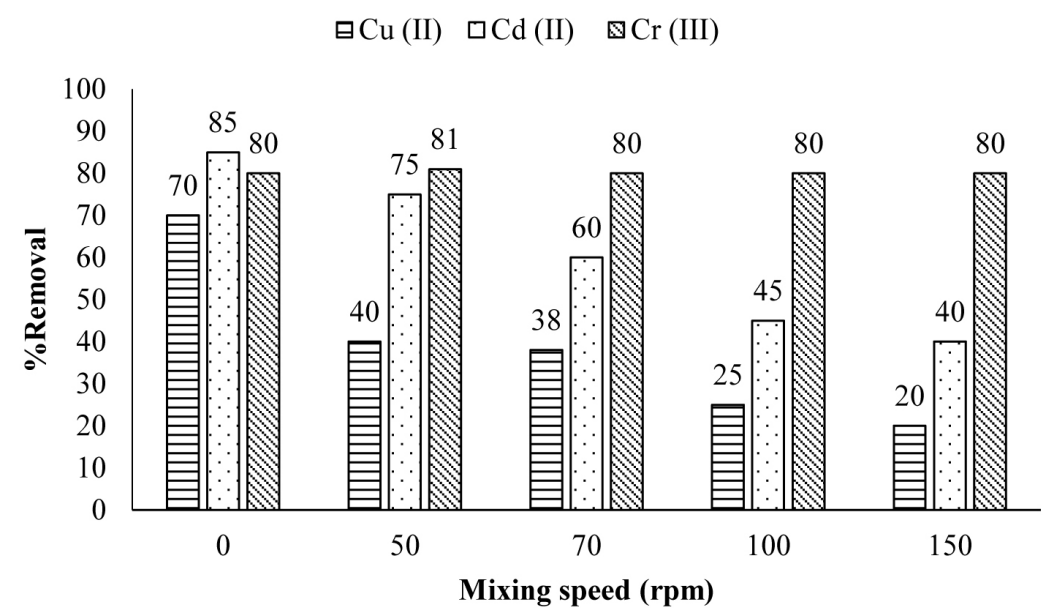

Fig. 2. Effect of mixing speed on removal efficiency 


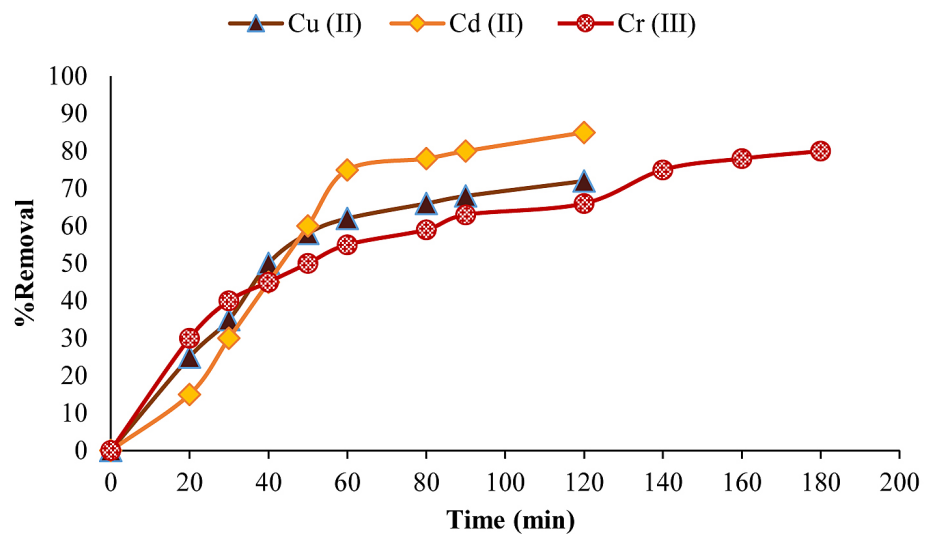

Fig. 3. Effect of contact time on $\mathrm{Cu}$ (II), Cd (II) and $\mathrm{Cr}$ (III) removal
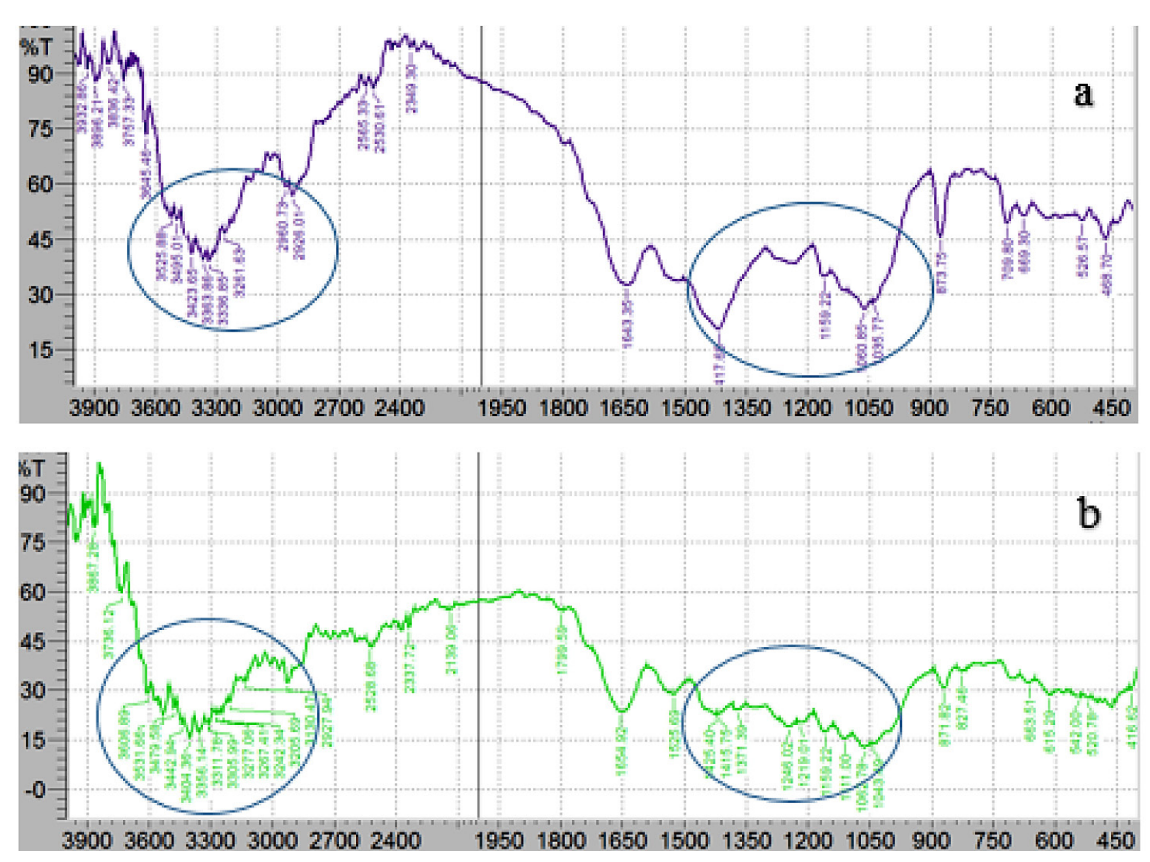

Fig. 4. FT-IR test for a) biosorbent before adsorption; b) biosorbent after adsorption

concentration and $1 \mathrm{~g} / \mathrm{L}$ biosorbent dosage. It is clear that the biosorption process passed through three stages. The removal in first stage is fast from 0 to 30 minutes for $\mathrm{Cu}$ (II) and $\mathrm{Cd}$ (II) and from 0 to 60 minutes for $\mathrm{Cr}$ (III). A lower rate can be achieved at second stage from 30 to 60 minutes for $\mathrm{Cu}$ (II) and $\mathrm{Cd}$ (II), and from 60 to $120 \mathrm{~min}$ utes for $\mathrm{Cr}$ (III), afterwards the process reaches the third stage which is saturated state. This may have occurred due to the availability of vacant surface sites in the biosorbent during the first stage, resulting in very quick adsorption of the heavy metal ions (Liu et al., 2015; Ghasemi et al., 2018).

\section{Surface characterization of biosorbent}

The macro algae biosorbent sample was characterized for its surface area (BET). The surface area was found as $1.4 \mathrm{~m}^{2} / \mathrm{g}$. Furthermore, Fourier transform infrared (FT-IR) spectroscopy (Fig. 4) was carried out to identify the functional groups and their changes before and after the biosorption process. These tests were conducted for the sample of best removal.

\section{CONCLUSION}

This study indicated that cladophora green algae, which are eco-friendly and widely available, can be used as an efficient biosorbent material for removal of $\mathrm{Cu}$ (II), $\mathrm{Cd}$ (II) and $\mathrm{Cr}$ (III) from wastewater. The removal rate was fast in the first 30 min, for $\mathrm{Cu}$ (II) and $\mathrm{Cd}$ (II), and first hour for $\mathrm{Cr}$ (III), then the removal rate slowed down until it reached study state. The best removal efficiency 
was $70 \%, 85 \%$ and $80 \%$ from the initial concentration for $\mathrm{Cu}$ (II), $\mathrm{Cd}$ (II) and $\mathrm{Cr}$, respectively. The best $\mathrm{pH}$ was 5.2 for copper, 7 for cadmium and 5 for chromium. Increasing the mixing speed had a negative effect on the removal efficiency, so the best removal was without mixing. The green algae were successfully proven as low cost biosorbent, especially that they do not need harsh temperature to be dried in, or any activation or chemicals to be added, unlike the conventional methods as activated carbon or chemical precipitation.

\section{Acknowledgments}

The authors would like to thank Al-Khwarizmi College of Engineering, Department of Biochemical Engineering, University of Baghdad and Iraqi Ministry of Higher Education for supporting this research project, and also express our gratitude to Universiti Kebangsaan Malaysia for a research collaboration through DIP-2018-006/3 grant.

\section{REFERENCES}

1. Awual, R. et al. 2016. Treatment of copper (II) containing wastewater by a newly developed ligand based facial conjugate materials. Chemical Engineering Journal, 288, 368-376.

2. Ayangbenro, A.S. and Babalola, O.O. 2017. A new strategy for heavy metal polluted environments: A review of microbial biosorbents. Int. J. Environ. Res. Public Health, 14(1), 94.

3. Aydın, H. and Bulut, Y. 2008. Removal of copper (II) from aqueous solution by adsorption onto lowcost adsorbents. Journal of Environmental Management 87(1), 37-45.

4. Ballester, A. et al. 1999. Biosorption of copper and zinc by Cymodocea nodosa. FEMS Microbiology Reviews 23(5), 527-536.

5. Bilal, M., Rasheed, T. and Eduardo, J. 2018. Biosorption: An interplay between marine algae and potentially toxic elements: A review. Marine Drugs, 16(2), 1-16.

6. Deng, L. et al. 2007. Sorption and desorption of lead (I) from wastewater by green algae Cladophora fascicularis. Journal of Hazardous Materials, 143(3), 220-225.

7. Ghasemi, N. et al. 2018. Zn (II) removal by aminofunctionalized magnetic nanoparticles: Kinetics, isotherm, and thermodynamic aspects of adsorption. Journal of Industrial and Engineering Chemistry, 62, 302-310.

8. Gong, X. et al. 2019. Biological regeneration of brewery spent diatomite and its reuse in basic dye and chromium (III) ions removal. Process Safety and Environmental Protection, 128, 353-361.

9. Gupta, P. and Diwan, B. 2017. Bacterial Exopolysaccharide mediated heavy metal removal: A review on biosynthesis, mechanism and remediation strategies. Biotechnology Reports, 13, March, 58-71.
10. He, J. and Chen, J.P. 2014. A comprehensive review on biosorption of heavy metals by algal biomass: materials, performances, chemistry, and modelling simulation tools. Bioresource Technology, 160, May, 64-78.

11. Hu, H. et al. 2017. Efficient removal of copper from wastewater by using mechanically activated calcium carbonate. Journal of Environmental Management, 203, 1-7.

12. Huang, J. et al. 2016. Influence of pH on heavy metal speciation and removal from wastewater using micellar enhanced ultrafiltration. Chemosphere, 173, April, 199-206.

13. Ismail, N. I. et al. 2019. Simultaneous bioaccumulation and translocation of iron and aluminium from mining wastewater by Scirpus grossus. Desalination and Water Treatment 163, 133-142.

14. Kadukova, J. and Virc, E. 2005. Comparison of differences between copper bioaccumulation and biosorption. Environment International, 31, 227-232.

15. Kamaruzzaman, M.A. et al. 2019. Potential of hexavalent chromium-resistant rhizosphere bacteria in promoting plant growth and hexavalent chromium reduction. Journal of Environmental Biology, 40, 427-433.

16. Labidi,A. etal. 2016. Adsorption of copper on chitin-based materials: Kinetic and thermodynamic studies. Journal of the Taiwan Institute of Chemical Engineers, 65, 140-148.

17. Lee, Y. and Chang, S. 2011. The biosorption of heavy metals from aqueous solution by Spirogyra and Cladophora filamentous macroalgae. Bioresource Technology, 102(9), 5297-5304.

18. Li, E., Zeng, X. and Fan, Y. 2009. Removal of chromium ion (III) from aqueous solution by manganese oxide and microemulsion modified diatomite. Desalination, 238(1-3), 158-165.

19. Liu, X. et al. 2015. Removal of methylene blue from aqueous solutions by an adsorbent based on metalorganic framework and polyoxometalate. Journal of Alloys and Compounds, 648, 986-993.

20. Ofomaja, A.E. 2010. Equilibrium studies of copper ion adsorption onto palm kernel fibre. Journal of Environmental Management, 91(7), 1491-1499.

21. Purwanti, I.F. et al. 2019. Aluminium removal and recovery from wastewater and soil using isolated indigenous bacteria. Journal of Environmental Management, 249, Article 109412.

22. Sedlakova-Kadukova, J. et al. 2019. Bioaccumulation and biosorption of zinc by a novel Streptomyces K11 strain isolated from highly alkaline aluminium brown mud disposal site. Ecotoxicology and Environmental Safety, 167, 204-211.

23. Titah, H.S. et al. 2019. Kinetics of aluminium removal by locally isolated Brochothrix thermosphacta and Vibrio alginolyticus. Journal of Environmental Management, 238, May, 194-200.

24. Titah, H.S. et al. 2018. Arsenic resistance and biosorption by isolated rhizobacteria from the roots of Ludwigia octovalvis. International Journal of Microbiology. Volume 2018, Article ID 3101498.

25. Tunali, S. et al. 2009. Removal of copper (II) ions from synthetic solution and real wastewater by the combined action of dried Trametes versicolor cells and montmorillonite. Hydrometallurgy, 97, 98-104. 